\title{
Terlipressin-induced skin necrosis
}

\author{
Gaurav Jain, ${ }^{1}$ Pooja Chandran, ${ }^{1}$ Itish Patnaik, ${ }^{2}$ Nupur B Patel (1) ${ }^{1}$
}

${ }^{1}$ Department of Anaesthesiology and Critical Care, AllMS

Rishikesh, Rishikesh,

Uttarakhand, India

2Department of

Gastroenterology, AllMS

Rishikesh, Rishikesh,

Uttarakhand, India

\section{Correspondence to}

Dr Nupur B Patel;

nupurbpatel@yahoo.co.in

Accepted 28 October 2021

\section{DESCRIPTION}

A 54-year-old chronic alcoholic presented with complaints of jaundice for 1 month and abdominal distension for 20 days. He also complained of decreased urine output for the last 3 days. He had no significant family history or comorbidities. Clinically he was icteric, had hepatosplenomegaly and moderate ascites on abdomen examination. Investigations revealed serum creatinine of $3.62 \mathrm{mg} / \mathrm{dL}$ with serum total bilirubin of $36.6 \mathrm{mg} / \mathrm{dL}$ and international normalised ratio (INR) of 1.8. The patient also had hypoalbuminaemia $(1.8 \mathrm{~g} / \mathrm{dL})$. He was started on albumin infusion $(1 \mathrm{~g} / \mathrm{kg})$, despite which he had progressive acute kidney injury (AKI), hence he was started on terlipressin $2 \mathrm{mg}$ intravenously every 4 hours. On the third day of therapy, we noticed bilateral reticulated nonblanching erythematous and purpuric macules and patches with bullae in both lower limbs (figure 1). Doppler ultrasound demonstrated normal arterial and venous blood flow. A diagnosis of terlipressin-induced skin necrosis was made, and terlipressin was stopped. There was regression of patches and signs of healing.

Terlipressin is a synthetic long-acting analogue of vasopressin, which is widely used in the treatment of patients with cirrhosis with hepatorenal syndrome and variceal bleeding. Although it causes a vasoconstrictive effect specifically on splanchnic circulation, a similar effect can be seen in the systemic circulation. Vasoconstrictor effects on the systemic circulation

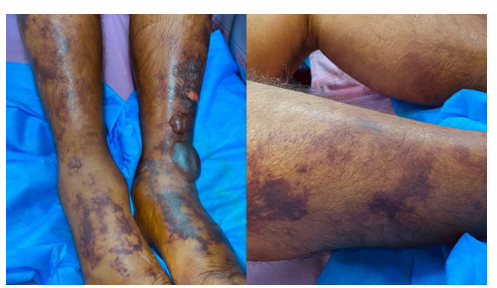

Figure 1 Bilateral reticulated nonblanching erythematous and purpuric macules and patches with bullae in both lower limbs.

\section{Learning points}

- Terlipressin-induced skin necrosis, although a rare complication, can lead to severe necrotising soft tissue infection.

- It is a dose-related side effect developing 3-5 days after starting terlipressin.

- The primary treatment is discontinuation of terlipressin.

result in ischaemic complications in $<5 \%$ of cases. In similar previously reported cases, the complication evolved after few days of treatment, thus indicating a dose-related effect. ${ }^{12}$ Although ischaemic complication with terlipressin is rare, it is important to consider in a patient presenting with erythematous purpuric patches in the skin on terlipressin.

Contributors NBP helped in planning, writing and submitting the case. GJ, PC and IP helped in writing the case.

Funding The authors have not declared a specific grant for this research from any funding agency in the public, commercial or not-for-profit sectors.

\section{Competing interests None declared.}

Patient consent for publication Consent obtained from next of kin.

Provenance and peer review Not commissioned; externally peer reviewed.

Case reports provide a valuable learning resource for the scientific community and can indicate areas of interest for future research.

They should not be used in isolation to guide treatment choices or public health policy.

\section{ORCID iD}

Nupur B Patel http://orcid.org/0000-0001-9929-0391

\section{REFERENCES}

1 Kulkarni AV, Kumar P, Rao NP, et al. Terlipressin-induced ischaemic skin necrosis. BMJ Case Rep 2020;13:e233089.

2 Ozel Coskun BD, Karaman A, Gorkem H, et al. Terlipressininduced ischemic skin necrosis: a rare association. Am J Case Rep 2014;15:476-9

Copyright 2021 BMJ Publishing Group. All rights reserved. For permission to reuse any of this content visit

https://www.bmj.com/company/products-services/rights-and-licensing/permissions/

BMJ Case Report Fellows may re-use this article for personal use and teaching without any further permission.

Become a Fellow of BMJ Case Reports today and you can:

- Submit as many cases as you like

- Enjoy fast sympathetic peer review and rapid publication of accepted articles

- Access all the published articles

Re-use any of the published material for personal use and teaching without further permission

\section{Customer Service}

If you have any further queries about your subscription, please contact our customer services team on +44 (0) 2071111105 or via email at support@bmj.com.

Visit casereports.bmj.com for more articles like this and to become a Fellow 